\title{
Analisis Potensi Likuefaksi pada Tanah Pasir Akibat Gempa (Studi Kasus Mataram, Nusa Tenggara Barat)
}

\author{
GEA NURBANI, YUKI ACHMAD YAKIN
}

\author{
Program Studi Teknik Sipil, Institut Teknologi Nasional Bandung \\ Email: geanurbani@gmail.com
}

\begin{abstract}
ABSTRAK
Pada hari Minggu, 5 Agustus 2018 pukul 19:46 WITA, gempa bumi mengguncang wilayah Labuan, Lombok, Nusa Tenggara Barat dengan skala magnitudo M7,0. Akibat guncangan tersebut, terjadi peristiwa likuefaksi di sebagian wilayah Provinsi Nusa Tenggara Barat dan menimbulkan kerusakan yang signifikan. Peristiwa likuefaksi dapat terjadi apabila mengalami peningkatan tekanan air pori yang dipicu oleh gempa bumi sehingga mengakibatkan tanah kehilangan kekakuan dan kuat geser tanah. Likuefaksi pada umumnya terjadi pada tanah pasir lepas dengan kondisi jenuh air. Dalam menganalisis potensi terjadinya likuefaksi di lokasi penelitian, digunakan nilai percepatan puncak di batuan dasar (PGA) sebesar 4,13 $\mathrm{m} / \mathrm{s} 2$ dan menggunakan data tanah hasil pengujian Standard Penetration Test (SPT). Hasil perbandingan antara ketahanan tanah atau Cyclic Resistance Ratio (CRR) dengan kemampuan tanah terlikuefaksi atau Cyclic Stress Ratio (CSR) menunjukkan bahwa likuefaksi terjadi pada rata-rata kedalaman 5,5 m-19.5 m.
\end{abstract}

Kata kunci: likuefaksi, cyclic stress ratio (CSR), cyclic resistance ratio (CRR), faktor keamanan (FK)

\begin{abstract}
On Sunday, August 52018 at 19:46 WITA, an earthquake has shook Labuan, Lombok, West Nusa Tenggara with magnitude 7.0 scale. As a result of the earthquake, liquefaction occurred in several regions of West Nusa Tenggara and caused severe damage. Liquefaction can occure when an increase in pore water pressure is triggered by an earthquake, which causes the soil losing its shear strength and stiffness. Liquefaction mostly occured in sand loose and saturated condition. Analysis of liquefaction based on Peak Ground Acceleration (PGA) at the research site $4.13 \mathrm{~m} / \mathrm{s} 2$ were done according to the data of SPT (Standard Penetration Test). By comparing the value of soil resistance to liquefaction or Cyclic Resistance Ratio (CRR) and the ability of soil to be liquefied or Cyclic Stress Ratio (CSR), the analysis shows the soil in that area are liquefied at depth of $5.5 \mathrm{~m}-$ $19.5 \mathrm{~m}$.
\end{abstract}

Keywords: liquefaction, cyclic stress ratio (CSR), cyclic resistance ratio (CRR), safety of factor (SF) 


\section{PENDAHULUAN}

Tanah pasir pada kondisi jenuh cenderung memampat ketika diberikan beban, salah satunya beban dinamis. Di Indonesia beban dinamis yang rawan terjadi adalah gempa bumi. Hal ini disebabkan karena letak Indonesia yang berada di titik pertemuan 3 lempeng tektonik aktif, yakni, lempeng Indo-Australia, Eurasia, dan Pasifik. Gempa bumi yang terjadi secara tiba-tiba di permukaan yang didominasi tanah pasir jenuh akan kehilangan tegangan efektif sehingga menyebabkan tanah berperilaku seperti cairan, peristiwa ini disebut dengan likuefaksi.

Salah satu daerah di Nusa Tenggara Barat, yaitu di wilayah Mataram, mempunyai frekuensi gempa yang cukup tinggi. Berdasarkan data yang diperoleh dari United States Geological Survey (USGS), gempa bumi terbesar yang pernah terjadi memiliki kekuatan hingga $M 7,0$. Gempa tersebut terjadi di Labuan, Lombok pada hari Minggu, 5 Agustus 2018 pukul 18:46 WIB. Titik pusat gempa bumi berada di $18 \mathrm{~km}$ barat laut Lombok Timur dengan kedalaman 32 $\mathrm{km}$. Selain itu berdasarkan data USGS, wilayah Mataram berpotensi mengalami likuefaksi ketika gempa bumi. Diperlukan analisis pada kondisi tanah pasir jenuh untuk mengetahui kenaikan tekanan air pori dan pengaruh beban siklik terhadap tanah yang diteliti dan agar dapat mengidentifikasi potensi likuefaksi serta dampak kerusakan yang ditimbulkan.

\section{KAJIAN PUSTAKA}

\subsection{Definisi Likuefaksi}

Menurut Ishihara, K. (1985), proses perubahan kondisi tanah dari padat menjadi cair terjadi ketika tegangan efektif tanah bernilai nol. Hal ini disebabkan tekanan air pori akan meningkat sampai ke titik yang sama dengan tegangan tanah, saat ada beban siklik. Likuefaksi terjadi ketika kondisi tanah kehilangan kekuatan (strength) dan kekakuan (stiffness) dalam waktu singkat akibat kehilangan kuat geser tanah. Menurut Kramer, S. L. (1996) likuefaksi umumnya terjadi di dekat sungai, teluk, atau badan air lainnya karena likuefaksi hanya terjadi pada tanah pasir jenur air. Kondisi tanah pada saat terjadi likuefaksi dapat dinyatakan dalam Persamaan 1.

$$
\sigma^{\prime}=\sigma-u
$$

halmana:

$$
\begin{aligned}
\sigma^{\prime} & =\text { tegangan efektif tanah }\left[\frac{\mathrm{t}}{\mathrm{m}^{2}}\right], \\
\sigma & =\text { tegangan total }\left[\frac{\mathrm{t}}{\mathrm{m}^{2}}\right], \\
u & =\text { tekanan air pori }\left[\frac{\mathrm{t}}{\mathrm{m}^{2}}\right] .
\end{aligned}
$$

Menurut Das, B. M. (1993) perhitungan tegangan total dapat menggunakan Persamaan 2.

$$
\sigma=\left(H * \gamma_{d}\right)+\left(H-H_{A}\right) * \gamma_{s a t}
$$

halmana:

$H \quad=$ tinggi muka air diukur dari permukaan tanah [m],

$H_{A} \quad=$ jarak antara titik A dengan muka air [m]

$\gamma_{d}=$ berat volume tanah kering $\left[\frac{\mathrm{t}}{\mathrm{m}^{3}}\right]$,

$\gamma_{\text {sat }}=$ berat volume tanah jenuh air $\left[\frac{\mathrm{t}}{\mathrm{m}^{3}}\right]$.

Sementara itu, perhitungan rasio tekanan air pori tanah dapat menggunakan Persamaan 3. 


$$
u=H_{A} * \gamma_{w}
$$

halmana:

$\gamma_{w} \quad=$ berat volume air $\left[10 \frac{\mathrm{kN}}{\mathrm{m}^{3}}\right]$.

\subsection{Faktor-faktor Penyebab Likuefaksi}

Faktor-faktor yang menyebabkan likuefaksi adalah sebagai berikut:

(a) intensitas gempa bumi, durasi, dan karakteristik gempa;

(b) jenis tanah;

(c) muka air tanah;

(d) kepadatan relatif awal (Initial Relative Density);

(e) ukuran gradasi dan bentuk partikel;

(f) kondisi drainase dan dimensi endapan;

(g) historis lingkungan.

\subsection{Proses Terjadinya Likuefaksi}

Likuefaksi terjadi pada tanah granular dengan kepadatan lepas hingga sedang dan elevasi muka air tanah yang tinggi. Ketika tidak ada getaran tanah akan stabil karena partikel tanah saling mengunci (interlocking). Ketika terjadi gempa, volume tanah cenderung menyusut seiring dengan meningkatnya tekanan air pori sehingga kekuatan interlocking antara partikel hilang.

\subsection{Metode Evaluasi Likuefaksi}

Seed, H. B. \& Idriss, I. M. (1971) mengusulkan metode sederhana untuk mengevaluasi potensi likuefaksi. Adapun langkah untuk mengevaluasi potensi likuefaksi adalah sebagai berikut:

\section{Cyclic Stress Ratio (CSR)}

Likuefaksi yang terjadi pada tanah pasir jenuh dikarenakan nilai Cyclic Stress Ratio (CSR) akibat gempa bumi. Menurut Seed, H. B. \& Idriss, I. M. (1971) perhitungan CSR menggunakan Persamaan 4.

$$
C S R=\frac{\tau_{a v}}{\sigma_{v}}=0,65 * \frac{\tau_{\max }}{\sigma^{\prime} v}=0,65\left(\frac{a_{\max }}{g}\right)\left(\frac{\sigma_{v}}{\sigma_{\prime_{v}}}\right) r_{d}
$$

halmana:

$$
\begin{array}{ll}
\tau_{a v} & =\text { tegangan geser rata-rata, } \\
\tau_{\text {max }} & =\text { tegangan geser siklik, } \\
\sigma_{v} & =\text { tegangan overburden vertikal total }\left[\frac{\mathrm{kN}}{\mathrm{m}^{2}}\right], \\
\sigma_{v}^{\prime} & =\text { tegangan overburden vertikal efektif }\left[\frac{\mathrm{kN}}{\mathrm{m}^{2}}\right], \\
\alpha_{\max } & =\text { percepatan permukaan tanah maksimum arah horizontal }\left[\frac{\mathrm{m}}{\mathrm{s}^{2}}\right], \\
r_{d} & =\text { koefisien reduksi kedalaman, } \\
g & =\text { percepatan gravitasi }\left[9,81 \frac{\mathrm{m}}{\mathrm{s}^{2}}\right] .
\end{array}
$$

Liao, S. S. C. \& Whitman, R. V. (1986) mengembangkan persamaan untuk mengestimasi reduksi tegangan berdasarkaan Persamaan 5.a sampai Persamaan 5.d.

$$
\begin{gathered}
r_{d}=1,0-0,00756 z \text { untuk } z \leq 9,15 \mathrm{~m} \\
r_{d}=1,174-0,0267 \mathrm{z} \text { untuk } 9,15 \mathrm{~m}<z \leq 23 \mathrm{~m}
\end{gathered}
$$




$$
\begin{gathered}
r_{d}=0,774-0,008 z \text { untuk } 23 \mathrm{~m}<z \leq 30 \mathrm{~m} \\
r_{d}=0,5 \text { untuk } z>30 \mathrm{~m}
\end{gathered}
$$

\section{Cyclic Resistance Ratio (CRR)}

Cyclic Resistance Ratio (CRR) merupakan kemampuan tanah untuk menahan likuefaksi. Parameter untuk menentukan CRR yaitu nilai penetrasi pada CPT, jumlah pukulan SPT, atau kecepatan gelombang geser, $V_{S}$ (Idriss, I. M. \& Boulanger, R.W., 2008).

3. Faktor Keamanan (FK)

Perhitungan faktor keamanan terhadap likuefaksi dapat menggunakan Persamaan 6.

$$
F K=\frac{C R R}{C S R}
$$

Potensi likuefaksi terjadi ketika tanah memiliki $F K<1,3$; kondisi kritis terjadi ketika memiliki $F K=1,3$; kondisi aman terjadi ketika tanah memiliki $F K>1,3$.

4. Liquefaction Potential Index (LPI)

Perhitungan untuk mengevaluasi potensi likuefaksi dapat menggunakan Persamaan 7.

$$
L P I=\int_{0}^{20} F(z) w(z) d z
$$

halmana:

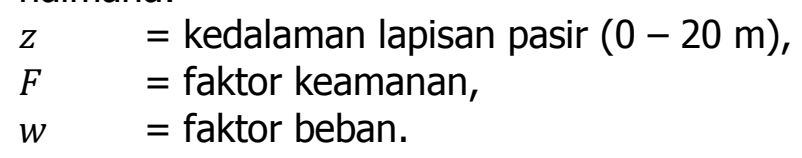

Kriteria untuk menentukan besarnya nilai faktor beban pada kedalaman 0 - 20 m seperti pada Persamaan 8.a sampai Persamaan 8.d.

$$
\begin{gathered}
F=1-F S \text { untuk } F K<1 \\
F=0 \text { untuk } F K \geq 1 \\
w=10-0,5 z \text { untuk } z<20 \mathrm{~m} \\
w=0 \text { untuk } z \geq 20 \mathrm{~m}
\end{gathered}
$$

Nilai LPI yang telah dihitung kemudian disesuaikan dengan Tabel $\mathbf{1}$ untuk menentukan mengetahui seberapa rentan tanah terhadap likuefaksi.

Tabel 1. Liquefaction Potential Index (LPI)

\begin{tabular}{cccc}
\hline LPI & Iwasaki, et al. (1982) & Luna, R. \& Frost, J. D. (1998) & MERM (2003) \\
\hline LPI $=0$ & Very low & Little to None & None \\
\hline $0<$ LPI $<5$ & Low & Minor & Low \\
\hline $5<$ LPI $<15$ & High & Moderate & Medium \\
\hline $15<$ LPI & Very high & Major & High \\
\hline
\end{tabular}

\subsection{Analisis Potensi Likuefaksi Berdasarkan Data SPT}

Langkah-langkah dalam menganalisis potensi likuefaksi berdasarkan data Standard Penetration Test (SPT) adalah sebagai berikut: 
1. Metode Seed, H. B. \& De Alba, P. (1985)

Dalam fokusnya, Seed, H. B. \& De Alba, P. (1985) mengusulkan nilai SPT yang telah dikoreksi menggunakan Persamaan 9.

$$
\left(N_{1}\right)_{60}=N_{m} * C_{N} * \eta=N_{m} * \frac{2,2}{1,2+\frac{\sigma^{\prime} v}{P a}} * 60 \%
$$

halmana:

$\left(N_{1}\right)_{60}=$ uji penetrasi standar nilai $N$ dikoreksi untuk prosedur pengujian lapangan,

$N_{m} \quad=\mathrm{N}$-SPT yang diperoleh dari hasil uji di lapangan,

$C_{N} \quad=$ faktor normalisasi $\left(N_{m}\right)$ terhadap tegangan overburden,

$\eta \quad=$ free-fall hammer dengan efisiensi energi $60 \%$,

$\mathrm{Pa} \quad=$ tekanan atmosfer $100 \mathrm{kPa}$ (1 atm).

Nilai koreksi SPT $\left(N_{1}\right)_{60}$ berdasarkan grafik hubungan antara CRR dengan $\left(N_{1}\right)_{60}$ seperti pada Gambar 1 dapat mempengaruhi nilai CRR.

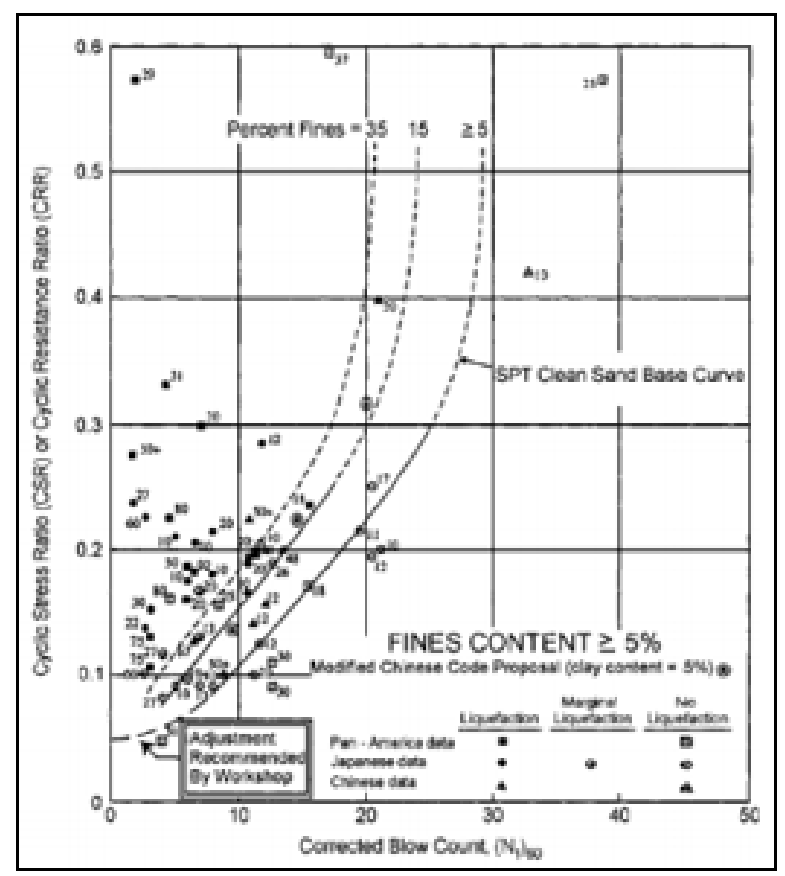

Gambar 1. Grafik hubungan antara $\left(N_{1}\right)_{60}$ dan CRR

(Sumber: Liquefaction resistance of soils: summary report from the 1996 NCEER and 1998 NCEER/NSF workshops on evaluation of liquefaction resistance of soils, 2001 (Modified from Seed et al., 1985))

2. Metode Youd, T. L., et al. (2001)

Metode ini lebih lebih fokus dalam menganalisis kemampuan tanah untuk terlikuefaksi (CRR). Youd, T. L., et al. (2001) memberikan koreksi terhadap nilai SPT dengan menggunakan Persamaan 10.

$$
\left(N_{1}\right)_{60}=C_{N} C_{E} C_{R} C_{B} C_{S} N_{m}
$$

halmana:

$C_{E} \quad=$ faktor koreksi rasio energy hammer(ER),

$C_{R} \quad$ = faktor koreksi panjang batang,

$C_{B} \quad=$ faktor koreksi diameter lubang bor, 
$C_{S} \quad=$ faktor koreksi sampel.

Menurut Seed, H. B. \& Idriss, I. M. (1982), diperlukan faktor koreksi seiring peningkatan nilai $\mathrm{N}-\mathrm{SPT}$ untuk perhitungan tegangan overburden menggunakan Persamaan $11(1 \mathrm{~Pa}=1$ atm).

$$
C_{N}=\frac{2,2}{\left(1,2+\frac{\sigma^{\prime} v o}{P a}\right)}
$$

Uraian faktor koreksi terhadap nilai SPT yang dimodifikasi dari Skempton, A. W. (1986) oleh Robertson, P.K. \& Wride, C. (1998) pada Tabel 2.

Tabel 2. Faktor Koreksi terhadap Nilai SPT

\begin{tabular}{|c|c|c|c|}
\hline Factor & $\begin{array}{l}\text { Equipment } \\
\text { Variabel }\end{array}$ & Term & Correction \\
\hline \multirow{2}{*}{$\begin{array}{l}\text { Overburden } \\
\text { Pressure }\end{array}$} & - & $C_{N}$ & \\
\hline & - & $C_{N}$ & \\
\hline \multirow{3}{*}{$\begin{array}{l}\text { Energy } \\
\text { Ratio }\end{array}$} & Donut Hammer & $C_{E}$ & $0,5-1,0$ \\
\hline & Safety Hammer & $C_{E}$ & $0,7-1,2$ \\
\hline & $\begin{array}{l}\text { Automatic-trip Donut } \\
\text { Type Hammer }\end{array}$ & $C_{E}$ & $0,8-1,3$ \\
\hline \multirow{3}{*}{$\begin{array}{l}\text { Borehole } \\
\text { Diameter }\end{array}$} & $65-115 \mathrm{~mm}$ & $C_{B}$ & 1 \\
\hline & $150 \mathrm{~mm}$ & $C_{B}$ & 1,05 \\
\hline & $200 \mathrm{~mm}$ & $C_{B}$ & 1,15 \\
\hline \multirow{5}{*}{ Rod Length } & $<3 \mathrm{~mm}$ & $C_{R}$ & 0,75 \\
\hline & $3-4 m m$ & $C_{R}$ & 0,8 \\
\hline & $4-6 \mathrm{~mm}$ & $C_{R}$ & 0,85 \\
\hline & $6-10 \mathrm{~mm}$ & $C_{R}$ & 0,95 \\
\hline & $10-30 \mathrm{~mm}$ & $C_{R}$ & 1,0 \\
\hline \multirow{2}{*}{$\begin{array}{l}\text { Sampling } \\
\text { Method }\end{array}$} & Standard Sampler & $C_{S}$ & 1,0 \\
\hline & $\begin{array}{l}\text { Sampler without } \\
\text { Liners }\end{array}$ & $C_{S}$ & $1,1-1,3$ \\
\hline
\end{tabular}

(Sumber: Liquefaction resistance of soils: summary report from the 1996 NCEER and 1998 NCEER/NSF workshops on evaluation of liquefaction resistance of soils, 2001)

Youd, T. L., et al. (2001) mengestimasi nilai koreksi $\left(N_{1}\right)_{60}$ terhadap fines content(FC) supaya ekuivalen dengan pasir bersih menggunakan Persamaan 12.

$$
\left(N_{1}\right)_{60 c s}=\alpha+\beta *\left(N_{1}\right)_{60}
$$

Dengan $\alpha$ dan $\beta$ adalah koefisien yang dapat ditentukan dengan Persamaan 13.a hingga Persaaan 13.d.

$$
\begin{gathered}
\alpha=0, \beta=1 \text { untuk } F C \leq 5 \% \\
\alpha=\exp \left[1,76-\left(\frac{190}{F C^{2}}\right)\right] \text { untuk } 5 \%<F C<35 \% \\
\beta=\left[0,99-\left(\frac{F C^{1,5}}{1000}\right)\right] \text { untuk } 5 \%<F C<35 \% \\
\alpha=5 ; \beta=1,2 \text { untuk } F C \geq 35 \%
\end{gathered}
$$


Perhitungan korelasi nilai CRR dengan nilai SPT pada saat terjadi gempa bumi dengan magnitudo $M=7,5$ menggunakan Persamaan 14.

$$
C R R_{7,5}=\frac{1}{34-\left(N_{1}\right)_{60 c s}}+\frac{\left(N_{1}\right)_{60 c s}}{135}+\frac{50}{\left[10 *\left(N_{1}\right)_{60 c s}+45\right]^{2}}-\frac{1}{200}
$$

\section{METODOLOGI PENELITIAN}

Penelitian yang dilakukan untuk tugas akhir ini dilakukan secara bertahap dan sistematis dalam bentuk bagan alir seperti yang ditunjukkan pada Gambar $\mathbf{2}$.

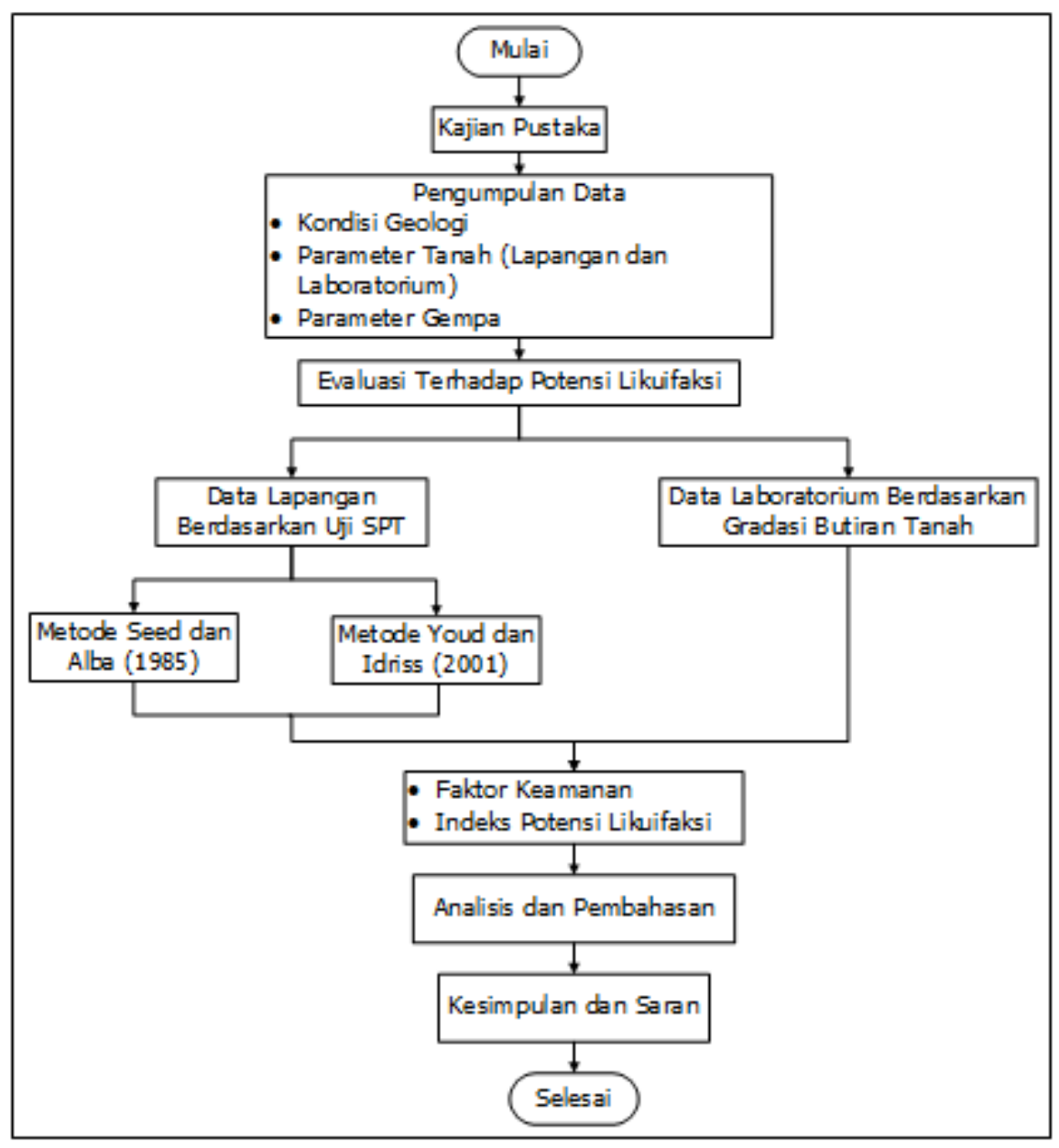

Gambar 2. Bagan alir penelitian

\subsection{Lokasi Penelitian}

Lokasi untuk penelitian ini berada di Kota Mataram, Nusa Tenggara Barat dengan koordinat seperti yang ditunjukkan Gambar 3. 


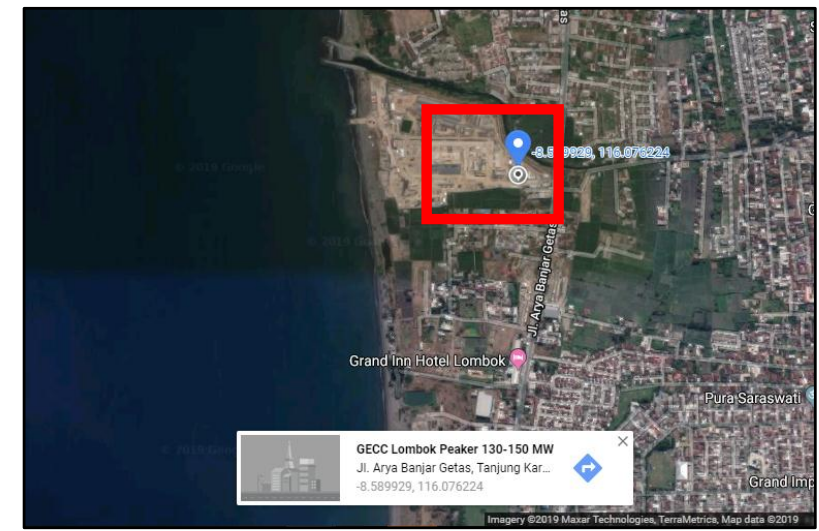

Gambar 3. Lokasi penelitian

(Sumber: US Dept of State Geographer, 2020)

\subsection{Pengumpulan Data}

Data lapangan berupa SPT diperoleh dari final report salah satu wilayah di Kota Mataram, Nusa Tenggara Barat dengan dilakukan 5 titik pengeboran. Data gempa bumi yang terjadi di Labuan, Lombok diperoleh dari USGS dan untuk rasio nilai percepatan tanah maksimum diambil berdasarkan Peta Zonasi Gempa Indonesia tahun 2017 untuk wilayah Mataram, Nusa Tenggara Barat.

\section{ANALISIS DAN PEMBAHASAN}

\subsection{Analisis Potensi Likuefaksi Berdasarkan Data SPT}

Adapun hasil analisis potensi likuefaksi berdasarkan data uji Standard Penetration Test(SPT) sebagai berikut.

1. Metode Seed, H. B. \& De Alba, P. (1985)

Berikut adalah data untuk BR - 03:

$$
\begin{array}{ll}
z & =9,5 \mathrm{~m} \\
m . a . t & =4,5 \mathrm{~m} \\
\gamma & =1,7 \mathrm{t} / \mathrm{m}^{3} \\
N & =12 \\
a_{\max } & =0,413 \times 9,81=4,052
\end{array}
$$

(a) Menghitung CSR

$$
\begin{array}{ll}
\sigma & =\sigma_{7,5}+(H * \gamma)=15,8 \frac{\mathrm{t}}{\mathrm{m}^{2}} \\
\sigma^{\prime} & =\sigma-\gamma_{w} *(H-\text { m.a.t })=10,8 \frac{\mathrm{t}}{\mathrm{m}^{2}} \\
r_{d} & =1,174-0,0267 z=0,920 \\
C S R & =0,65\left(\frac{a_{\max }}{g}\right)\left(\frac{\sigma_{v}}{\sigma_{v}}\right) r_{d}=0,361
\end{array}
$$

(b) Menghitung CRR

$$
\left(N_{1}\right)_{60}=N_{m} * \frac{2,2}{1,2+\frac{\sigma_{v}^{\prime} v}{P a}} * 60 \%=6,947
$$

Didapatkan nilai CRR berdasarkan grafik Seed, et al. (1985) sebesar 0,16.

(c) Menghitung FK

$$
F S=\frac{C R R}{C S R}=\frac{0,16}{0,361}=0,434
$$


Karena nilai faktor keamanan FS $<$ 1,3 maka tanah aman dan berpotensi terjadi likuefaksi.

2. Metode Youd, T. L., et al. (2001)

Data BR - 03 dan perhitungan CSR sama seperti pada metode Seed, H. B. \& De Alba, P. (1985). Perbedaannya terdapat saat menghitung CRR.

(a) Menghitung CRR

Nilai untuk faktor koreksi diambil berdasarkan Tabel $\mathbf{2}$ dengan uraian sebagai berikut:

$C_{N}=\frac{2,2}{1,2+\frac{\sigma^{\prime} v}{P a}}=0,96$

$C_{E}=0,8$

$C_{B}=1$

$C_{R}=0,95$

$C_{S}=1$

$N_{m}=1$

$\left(N_{1}\right)_{60}=C_{N} C_{E} C_{R} C_{B} C_{S} N_{m}=9$

$F C=18 \%$

$\alpha=\exp \left[1,76-\left(\frac{190}{F C^{2}}\right)\right]=3,234$

$\beta=\left[0,99-\left(\frac{F C^{1,5}}{1000}\right)\right]=0,914$

$\left(N_{1}\right)_{60 c s}=\alpha+\beta *\left(N_{1}\right)_{60}=11,274$

$\mathrm{CRR}_{7,5}=\frac{1}{34-\left(N_{1}\right)_{60 c s}}+\frac{\left(N_{1}\right)_{60 c s}}{135}+\frac{50}{\left[10 * x\left(N_{1}\right)_{60 c s}+45\right]^{2}}-\frac{1}{200}=0,123$

(b) Menentukan Faktor Keamanan

$M S F \quad=\frac{10^{2,24}}{M w^{2,56}}=1,238$

FS $\quad=\frac{C R R}{C S R} * M S F=0,412$

Karena nilai faktor keamanan $F S<1,3$ maka tanah tidak aman dan berpotensi terjadi likuefaksi. Hasil potensi lekuifaksi bor lainnya dapat dilihat pada Tabel 3.

Tabel 3. Hasil Perhitungan Potensi Likuefaksi Wilayah Mataram

\begin{tabular}{cccccc}
$\begin{array}{c}\text { Kedalaman } \\
{[\mathbf{m}]}\end{array}$ & \multicolumn{4}{c}{ Analisis Potensi Likuefaksi Berdasarkan Data SPT } \\
\cline { 2 - 5 } & BR - 01 & BR - 02 & BR - 03 & BR - 04 & BR - 05 \\
\hline 1,5 & Tidak Likuefaksi & Tidak Likuefaksi & Tidak Likuefaksi & Tidak Likuefaksi & Tidak Likuefaksi \\
\hline 3,5 & Tidak Likuefaksi & Likuefaksi & Tidak Likuefaksi & Tidak Likuefaksi & Tidak Likuefaksi \\
\hline 5,5 & Tidak Likuefaksi & Likuefaksi & Likuefaksi & Likuefaksi & Likuefaksi \\
\hline 7,5 & Tidak Likuefaksi & Likuefaksi & Likuefaksi & Likuefaksi & Likuefaksi \\
\hline 9,5 & Likuefaksi & Likuefaksi & Likuefaksi & Likuefaksi & Likuefaksi \\
\hline 11,5 & Likuefaksi & Likuefaksi & Likuefaksi & Likuefaksi & Likuefaksi \\
\hline 13,5 & Likuefaksi & Likuefaksi & Tidak Likuefaksi & Likuefaksi & Likuefaksi \\
\hline 15,5 & Likuefaksi & Likuefaksi & Likuefaksi & Likuefaksi & Likuefaksi \\
\hline 17,5 & Likuefaksi & Likuefaksi & Tidak Likuefaksi & Tidak Likuefaksi & Tidak Likuefaksi \\
\hline 19,5 & Tidak Likuefaksi & Tidak Likuefaksi & Tidak Likuefaksi & Tidak Likuefaksi & Tidak Likuefaksi \\
\hline
\end{tabular}

Berdasarkan evaluasi potensi likuefaksi didapat hubungan antara nilai CSR, CRR, dan faktor keamanan terhadap kedalaman seperti pada Gambar 4 sampai dengan Gambar 9. 


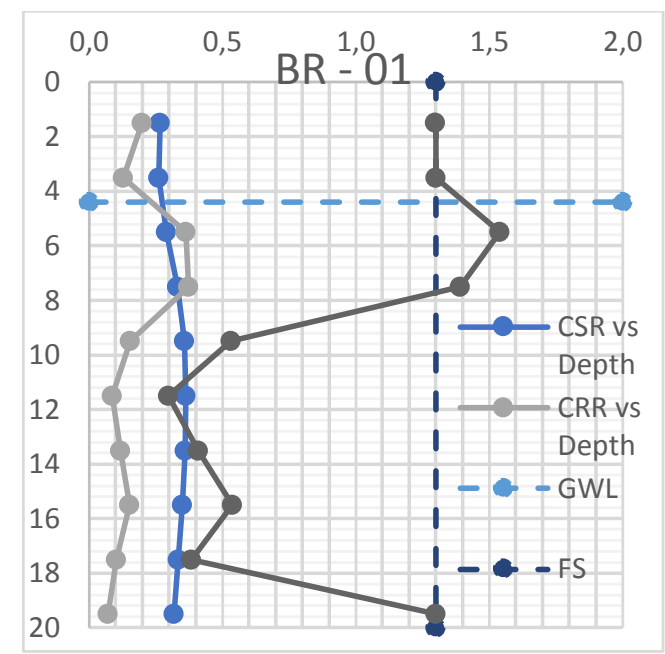

Gambar 4. Grafik bubungan antara CSR, CRR, dan FS dengan kedalaman pada $B R-01$

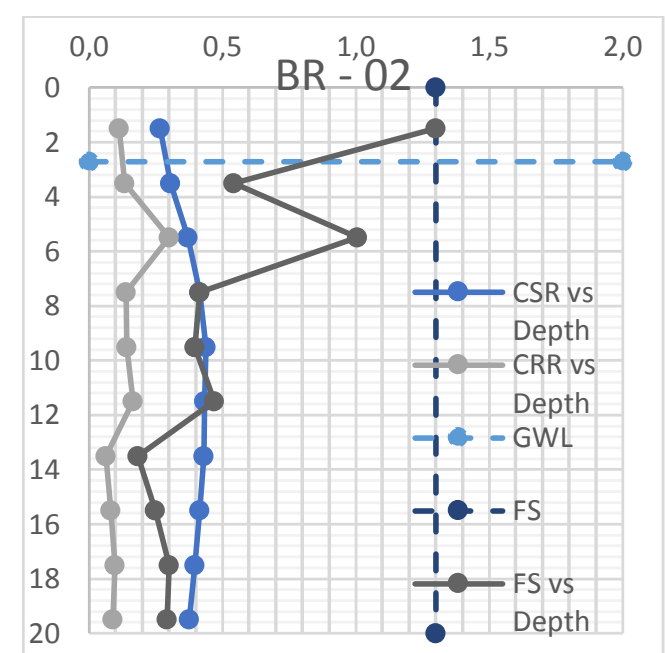

Gambar 5. Grafik bubungan antara CSR, CRR, dan FS dengan kedalaman pada $B R-02$

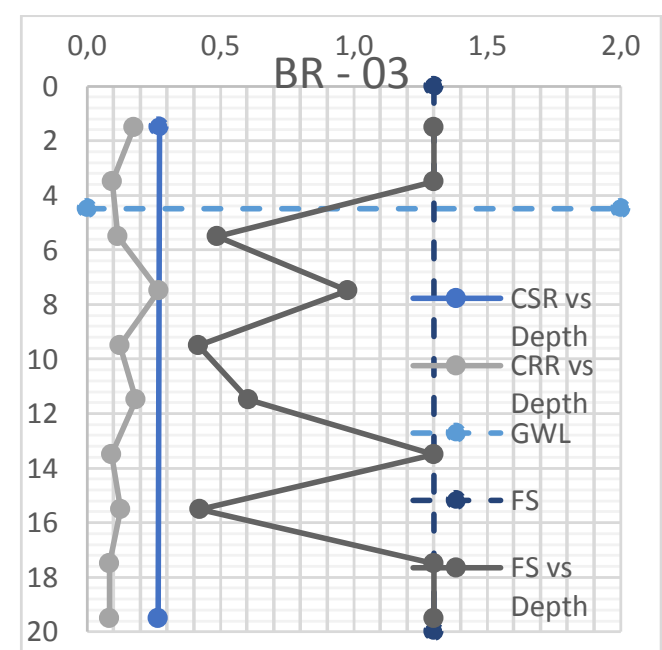

Gambar 6. Grafik bubungan antara CSR, CRR, dan FS dengan kedalaman pada $B R-03$ 


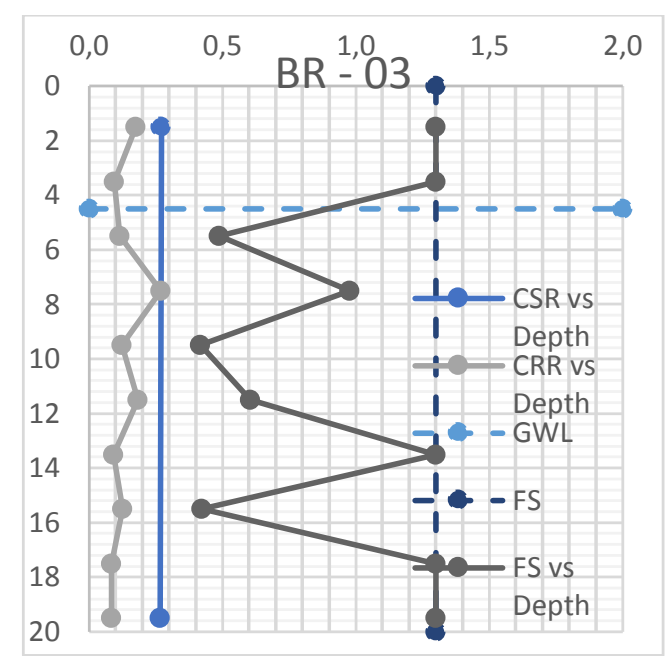

Gambar 7. Grafik bubungan antara CSR, CRR, dan FS dengan kedalaman pada $B R-03$

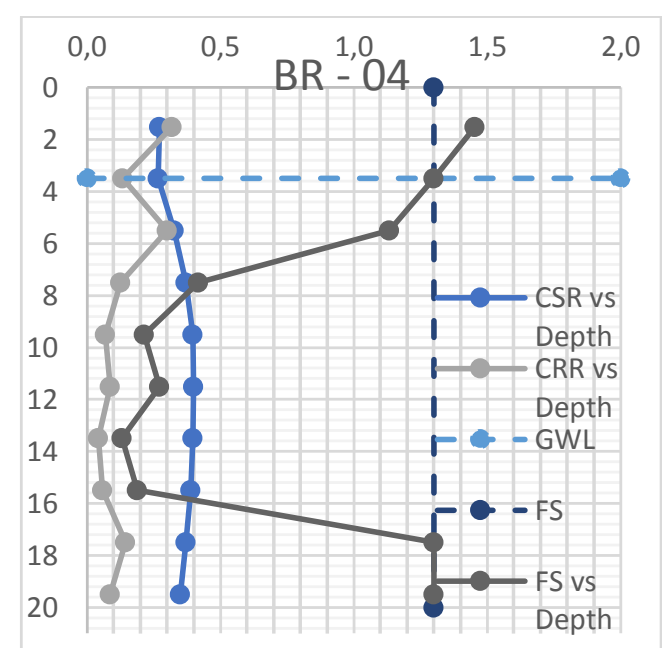

Gambar 8. Grafik bubungan antara CSR, CRR, dan FS dengan kedalaman pada $B R-04$

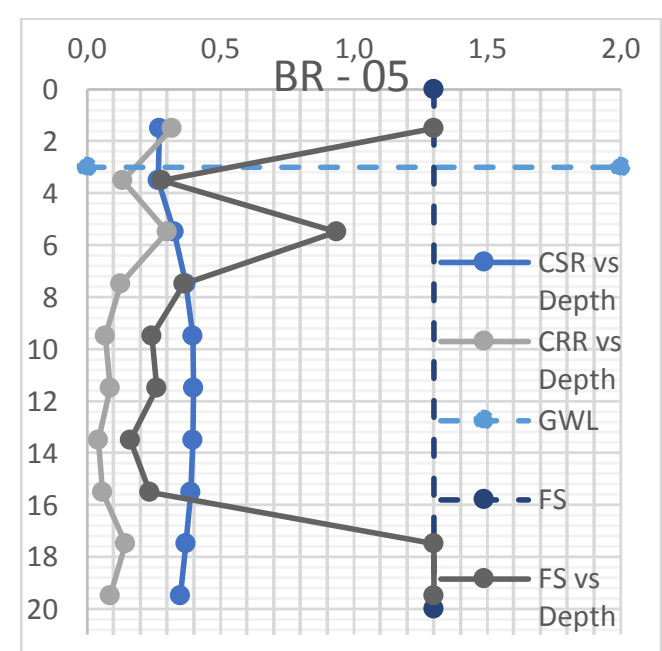

Gambar 9. Grafik bubungan antara CSR, CRR, dan FS dengan kedalaman pada $B R-05$ 


\subsection{Liquefaction Potential Index (LPI)}

Berikut adalah data hasil analisis untuk BR - 03 di kedalaman 9,5 m menggunakan metode Youd, T. L., et al. (2001) untuk mengetahui seberapa rentan lapisan tanah terhadap likuefaksi.

$$
\begin{array}{ll}
z & =9,5 \mathrm{~m} \text { untuk } z<20 \mathrm{~m} \\
F S & =0,412 \text { untuk } F S<1 \\
F & =1-F S=1-0,412=0,588 \\
w & =10-0,5 z=10-(0,5 * 2)=9 \\
\text { LPI } & =\int_{0}^{20} F(z) w(z) d z=\int_{0}^{2}(0,588 * 9) d z=10,94
\end{array}
$$

Untuk mengetahui kerentanan tanah terhadap likuefaksi, nilai LPI terlebih dahulu dihitung setiap lapisan tanah yang terlikuefaksi kemudian dikumulatif dan gunakan Tabel 1. Pada metode Youd, T. L., et al. (2001) di BR - 03 memiliki nilai LPI 9,97.

\subsection{Analisis Potensi Likuefaksi Berdasarkan Gradasi}

Berdasarkan perhitungan distribusi butiran diperoleh hasil seperti pada Gambar 10.

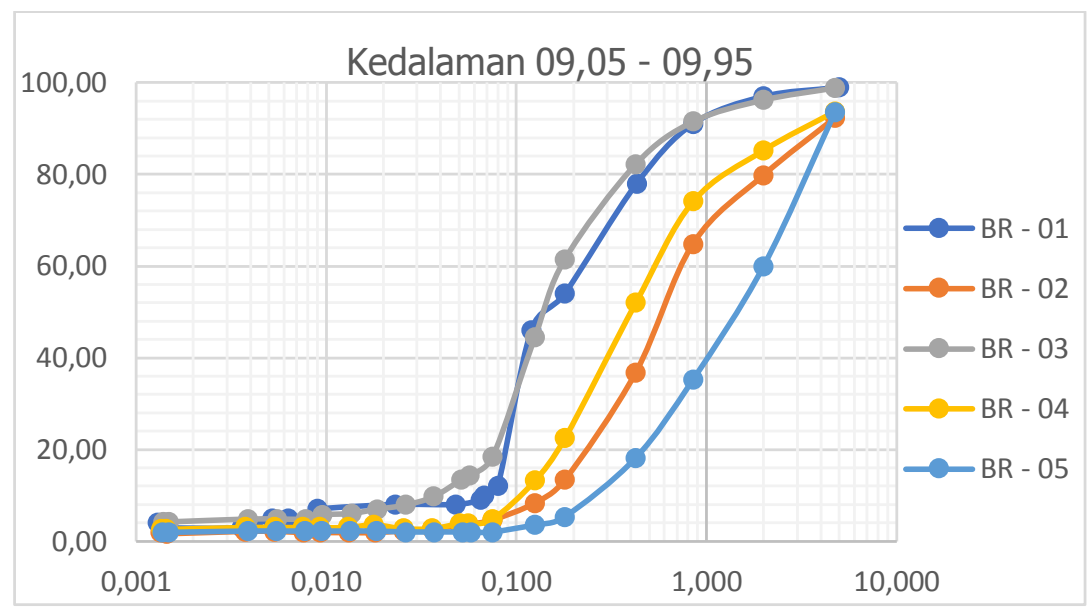

Gambar 10. Hasil Perhitungan Gradasi Butiran Kedalaman 09,05 - 09,95

\section{KESIMPULAN}

Berdasarkan hasil analisis dan pembahasan dalam penelitian dapat disimpulkan sebagai berikut:

1. Berdasarkan hasil perhitungan $B R-01$ mengalami likuefaksi setebal $8 m, B R-02$ setebal $18 \mathrm{~m}, \mathrm{BR}-03$ setebal $8 \mathrm{~m}, \mathrm{BR}-04$ setebal $10 \mathrm{~m}$, dan BR - 05 setebal $12 \mathrm{~m}$.

2. Hasil yang diperoleh untuk nilai CSR relatif sama pada kedua metode yang digunakan.

3. Hasil nilai CRR ada sedikit perbedaan antara kedua metode karena pada metode Seed, $\mathrm{H}$. B. \& De Alba, P. (1985) perlu ketelitian lebih karena menggunakan grafik.

4. Evaluasi tingkat likuefaksi di lokasi penelitian berdasarkan nilai LPI memiliki tingkat sedang sampai tinggi.

5. Potensi likueefaksi dapat diketahui berdasarkan gradasi butiran tanah.

\section{DAFTAR RUJUKAN}

Das, B. M. (1993). Mekanika Tanah (Prinsip-prinsip Rekayasa Geoteknis). Jakarta: Erlangga. Idriss, I. \&. (2008). Soil Liquefaction during Earthquake. Oakland: Earthquake Engineering Research Institute.

Ishihara, K. (1995). Earthquake Geotechnical Engineering. Rotterdam: CRC Press/Balkema. 
Iwasaki, T., Arakawa, T. \& Tokida, K. (1982). Simplified procedures for assessing soil liquefaction during earthquakes. The Conference on Soil Dynamics and Earthquake (p. 925-939). Southampton:

Kramer, S. L. (1996). Geotechnical Earthquake Engineering. London: Pearson.

Liao, S. S. C. \& Whitman, R. V. (1986). Overburden Correction Factors for SPT in Sand. Journal of Geotechnical Engineering, 112(3), 373-377.

Luna, R. \& Frost, J. D. (1998). Spatial liquefaction analysis system. Journal Comput. Civil Eng., $12,48-56$.

MERM. (2003). Microzonation for Earthquake Risk Mitigation (MERM): Microzonation Manual, World Institute for Disaster Risk Management. _ : World Institute for Disaster Risk Management.

Robertson, P.K. \& Wride, C. (1998). Evaluating Cyclic Liquefaction Potential Using the Cone Penetration Test. Canadian Geotechnical Journal, 35, 442-459.

Seed, H. B. \& De Alba, P. (1985). Use of SPT and CPT tests for evaluating the liquefaction resistance of sands. The Conference on Use of in Situ Tests in Geotechnical Engineering (pp. 281-302). Blacksburg: American Society of Civil Engineers.

Seed, H. B. \& Idriss, I. M. (1971). Simplified Procedure for Evaluation Soil Liquefaction Potential. Journal of the Soil Mechanics and Foundations Division, 97(9), 1249-1273.

Seed, H. B. (1982). Ground Motions and Soil Liquefaction During Earthquakes. Berkeley, Calif: Earthquake Engineering Research Institute.

Seed, H. B., Tokimatsu, K., Harder, L. F. \& Chung, R. M. (1985). Influence of SPT Procedures in Soil Liquefaction Resistance Evaluation. Journal of Geotechnical Engineering, 111(12), 1452-1445.

Skempton, A.W. (1986). Standard Penetration Test Procedures and the Effects in Sand of Overburden Pressure, Relative Density, Particle Size, Ageing and Overconsolidation. Géotechnique, 36, 425-447.

US Dept of State Geographer . (2020, Oktober 20). Google. Retrieved Oktober 20, 2020, from Google Earth: https://earth.google.com/web/search/GECC+Lombok+Peaker+130150+MW,+Jalan+Arya+Banjar+Getas,+Tanjung+Karang,+Mataram+City,+West+Nu sa+Tenggara,+Indonesia/@-

8.5899563,116.0761923,10.26875008a,1043.2857692d,35y,0h,45t,0r/data=CuABGrU BEq4BCiUweDJkY2RiZjg4MGQ2Y

Youd, T. L., Idriss, I. M., Andrus, R.D., Arango, I., Castro, G., Christian, J. T. \& et al. (2001). Liquefaction resistance of soils: summary report from the 1996 NCEER and 1998 NCEER/NSF workshops on evaluation of liquefaction resistance of soils. Journal of Geotechnical and Geoenvironmental Engineering, 127(10), 817-833. 